\title{
Lars Levi Læstadius’ Attitude to Saami Religion
}

\author{
By Carl F. Hallencreutz
}

How Læstadianism became the "religion of the Saamis" is a process of church and religious history which has not been fully explained. It is a comprehensive development which includes most of Læstadius' entire ministry. But also included in it is not least his attitude towards to the old religion of the Lapps.

It is this question which I propose to address in this paper. By this I mean not so much Læstadius' religious studies and interpretation of Saami religion-or "Lapp mythology" as he preferred to call it. Rather, my approach is from the missionary perspective. I am interested in how Læstadius took account of-or afforded expression to-motives from traditional Saami mythology when he formulated and adapted his own interpretation of Christianity to the Saami environment.

This problem should naturally be studied in any study of how Læstadianism became the "religion of the Saamis". It can, however, also contribute to a better understanding of Læstadius' endeavours themselves. The fact that Læstadius inherited a knowledge of Saami language on his mother's side and Swedish on his father's-added to which he learned Finnish later in life-casts important light on this question.

\section{The chronology of Læstadius' church work}

In a missionary study of Læstadius' place in the emergence of Læstadianism as the "religion of the Saamis" " it is important to delimit three periods in Læstadius' ministry, each of which expresses different aspects of his attitude towards the earlier beliefs of the Saamis. The first of these periods was Læstadius' time as a "Saami missionary" in Arjeplog from 1825 to 1826 and then as vicar in the Swedish part of Enontekiö parish, or Karesuando, until 1843.

The second period was the dramatic phase from June 1843 to May 1844, which includes the time when he passed his pastoral examination in Härnösand and his subsequent visit on behalf of Bishop Franzen to the Saami parishes from Föllinge in Jämtland in the south to Vittangi in the 
north. His own parish of Karesuando was not included in the official episcopal visit.

It was during this period that Læstadius, in early January 1844, met his Maria, or Milla, Clemensdotter at Asele and that, according to his own autobiography and to latterday tradition-particularly Læstadianism as the "religion of the Saamis", - - he underwent his conversion or experienced his second religious breakthrough. I term this course of events as Læstadius' personal and pastoral change.

Finally, the third period comprises Læstadius' time as parish priest and revivalist critical of the established church, once more in Karesuando -from 1844 - and in Pajala-from 1849 until his death in 1861.

As I have already indicated, each of these three periods actualises important contributions to Læstadius' attitude to old Saami beliefs. As far as the study of Læstadianism as the "religion of the Saamis" " is concerned, the question of whether we can discern any decisive changes in Læstadius' attitude to Saami religion after 1844 is, of course, decisive. I shall attempt to prove that such changes did take place. In order to do so, I must first, however, clarify what was characteristic of Læstadius' missionary attitude throughout his wholehearted career as "Saami missionary" and parish priest in Lappland from 1825 to 1843 .

\section{Læstadius' position as "Saami missionary" and minister in Lapland}

The first phase of Læstadius' ministry is often overlooked. Frequently, it is interpreted in a negative way. However, efforts are being made in research into Læstadius to adopt a more balanced assessment. As part of this trend, Gunnar Wikmark, for example, makes an energetic-even one-sided attempt to rehabilitate the young Læstadius and the Karesuando parish in Lars Levi Læstadius' väg till nya födelsen, 1980.

For anyone studying the development of Læstadianism into the "religion of the Saamis', ' the period $1825-43$ is undoubtedly a period of fundamental importance. During this period Læstadius and his fellow workers Anders Fjellner and Juhani Raattamaa came into close contact with the Swedish Saamis of the Kalott region. It was then that he began his campaign against the sale of alcohol and the abuse of strong drink in Lappland. He offered a Christian theological instrument and insights, which came fully into their own after the Læstadian revival had begun to make itself fully felt subsequent to 1845 .

The first phase of Læstadius' ministry occurred during a transition stage in Swedish ecclesiastical history in Lappland. The Saami parishes were, 
unlike the praxis during the Saami administration's epoch, to satisfy the Saami population's spiritual needs by means of divine services in the parish's main church and through ambulatory catechetical teaching. Petrus Læstadius, however, criticised this policy and recommended the establishment of fixed schools for the Saamis. From 1835 onwards the Swedish Missionary Society started to set up special Saami schools and school homes, especially in the southern Lapp areas.

Reports of episcopal visits and ecclesiastical activities from the Härnösand provincial archives bear witness to Læstadius' wholehearted efforts to promote official parochial and education policy after 1820 . In a very detailed comment on Dean Wikström's inspection report, dated February 4, 1836, Læstadius gives a careful account of current activities and how they had been adapted to existing conditions among the Saamis.

Such eucharist was held on Sundays in the parish church. The sermon was usually in Finnish. Læstadius adds, however, that "on certain feast days, such as Boxing Day and Easter Monday, for example, I have preached the sermon in Lappish but the preparatory service has been in Finnish". He also notes that the celebration of certain special days of prayer had been adapted to the Saamis' nomadic migrations. No day of intercession was held in the summer for "from the beginning of May until the end of November the Lapp people cannot visit their parish church since this section of the congregation spends the spring and autumn $100 \mathrm{~km}$ away and the summer in Norway 160-200 km distant from the church" (HDA F III bf 11,1836 ).

For the same a 3-4 week intensive course during the weeks before Easter with the actual confirmation ceremony taking place on Good Friday.

The work in the parish church had to be supplemented with special ambulatory work to take care of the Saami population in the northern part of the Enontekiö or Karesuando parish. Lastadius acknowledges the value of Fjellner's and Raattamaa's work. He also gives examples of how he himself made great efforts to visit the Saamis in the nomadic sites. He describes in detail how he prepared a visit to Saami families. His description is strongly coloured with local details and is given in a special appendix.

Læstadius' account of his work reveals his concern for the Saamis' spiritual welfare and a readiness to adapt the routines of the estblished Lutheran church to local conditions. It was almost inevitable that this period of parish work should give Læstadius insights and impulses that would lead to his adopting a direct personal stand when, from 1844 on, his preaching took on "a more colourful tone" and he began to agitate more openly to further "living Christianity" among the parishioners of Karesuando. 
Against this background it is important to draw attention to three other things that directly link Læstadius' involvement during the first period of his ministry with his work as an out-and-out revivalist in the years after 1844. The first was his struggle against the trade in alcohol and the abuse of strong drink in Lappland.

As early as the report of 1836 Læstadius draws attention to the problem, even if he did not yet find it so acute as elsewhere. Soon after, however, he found cause to take up in writing these new problems and mobilise the Saami population against the abuse of alcohol. His first document is in the form of three dialogues "between a Christian and an ordinary person" (Læstadius 1839), which Læstadius cites in a letter to the episcopal chapter in Härnösand as a suitable textbook for people settling in Lappland for learning the northern Saami dialect. The second is formulated as a sermon given on Boxing Day (Prediko Nobbe Jåluå Peiwen nalu, maw lå tjalam; Laestadius 1842). Both these pamphlets are marked by Læstadius' declared intention to make northern Saami an accepted literary language. They also place the warning against the abuse of alcohol in a conscious Christian doctrinal framework. Drinking is placed on the same footing as the preChristian "idolatrous church":

Listen, then, what life you lead! Your predecessors worshipped seiti and saivoplaces, stones and tree stumps. They crept and crawled on all fours before fallen trees and uprooted stumps. But you have begun to creep before other idols. You have taken your stomachs as your god. It says in the Scriptures, "He who drinks, he worships idols". And what is he who drinks strong drink but the most abject worshipper of idols (Læstadius 1978, 28).

For this "sin" the Christian shall make atonement through Jesus Christ and life in the forgiveness of sins (Læstadius 1978, 13). Læstadius is not content with using only pastoral arguments, however. In a letter of May 27, 1842 to the episcopal chapter in which he mentions his Boxing Day sermon and requests money to publish it he stresses that the aim of this sermon (Læstadius describes it as a "thesis") is in fact "to prepare opinion among the Saamis for the establishment of teetotal societies"' (HDA F IX a 4).

References to these pamphlets anticipate the second element in Læstadius' early work, an element which directly prepares the way for the development of Læstadianism into the "religion of the Saamis". I refer to his efforts to create a northern Saami written language, the most significant of which was his composition of the Biblical compendium Ancient Tales of God and Men (Tåluts Suptsasah, Jubmela pirra ja Almatji pirra; (Læstadius 1884).

As early as the report on activities made in 1836 Læstadius pointed out the pedagogical value in discussion of both private and general questions of 
life of "oral accounts from the biblial history of the Old and New Testament". This compendium, which Læstadius finally completed editing after his pastoral examination in Härnösand on October 7, 1843, reveals in truth a very pedagogical approach in his attempt to bring the Old Testament to life. The penultimate chapter, in which Læstadius sums up and adapts "God's promises of the Redeemer", is of particular importance (Læstadius $1978,171 \mathrm{ff}$.).

In his introductory "Erinran till wördiga Presterskapet i Lappmarken" (Admonition to the worthy Ministry in Lappland) of December 15, 1843, however, Læstadius adopts a somewhat different tone. He is almost apologetic when making a linguistic point: "The author is of the view that both the Lapp language and the Lapp people will die out first in the southern part of Lappland, for which reason all books published in Lappish hereafter should be in the northern dialect, which is any case the most recent and will last the longest'" (Læstadius 1978, 34).

During the first part of his appointment Læstadius was also closely involved in Saami field studies along the lines of Linnæus, Pehr Högström and Carl Erik Læstadius. He was particularly interested in Botany.

In his autobiography of the early part of the 1850's Læstadius takes a critical view of his early interest in natural science. Judging by what he says in the report of 1836 these studies may also have interfered with his duties as vicar. Læstadius admits "[...] since not only all Lapps are to be found on the north side of the ridge but also all those among the settlers who are capable of working are to be found in the vicinity of distant mountain lakes, the author has sometimes visited different mountain areas both within and without the parish area in the interests of natural history; during this time missionary Anders Fjellner has always been present at the church to hold divine service should there be anybody wishing to hear it" (HDA F III bf 11, 1836).

This was the situation in the summer of 1838 , when Læstadius at the order of Karl XIV Johan accompanied the French Recherche expedition led by P. Gaimard from Hammerfest to Karesuando. It was in this connection that he was inspired to put together his Fragmenter i Lappska Mythologien (Fragments of Lapp Mythology), which Harald Grundström has made accessible for wider study (Læstadius 1959).

I am not the man in this worthy company to make any kind of expert comment on Læstadius' contributions to the study of Saami religion. I shall confine myself to examining how these Fragmenter can contribute to an understanding of Læstadius' attitude to Saami religion.

Generalising to some extent, we may say that the Norwegian mission to the Saamis, from Thomas von Westen onwards, was marked by a conscious 
effort to describe Saami beliefs while at the same time renouncing them as "the works of the devil". A Swedish tradition dating back to Pehr Högström has adopted a more anthropological approach to traditional Saami religion, which it was considered should be replaced by Christian beliefs and practices but not be entirely condemned. In his admonition to the reader who goes so far as to enter into debate with Karl Axel Gottlund on the topic of pre-Christian religion Læstadius makes a similar comment even though he is of the opinion that the official Swedish attitude to the Saami shamans was more critical than the Norwegian (Læstadius 1959, 24).

Læstadius takes an independent view. He is attracted to Saami mythology and therefore follows to a large extent the Norwegian tradition in his interpretation of "Gudaläran', (Læstadius 1959, $37 \mathrm{ff}$.). At the same time, however, he makes wide use of the concept mythology and can provide accounts of folk tales of "supernatural beings and events" in addition to the "Gudaläran" (Læstadius 1959, 29). In this he is able to build on Högström's Lappmarksbeskrivning as well as on his own field studies (Högström 1747).

In his Fragmenter Læstadius refrains from pursuing an a priori negative attitude, dictated by Christian theological thinking, to the beliefs that he is studying. Prompted by Högström, he reflects on cause and effect in the development of Jubmel as the Saami god of thunder and sky (Læstadius $1959,42 \mathrm{ff}$.) and rejects diffusion theories. He casts light on the connection between the Saiwo dimension of existence and the shaman's behaviour and goes far in his attempt to explain the behavioural patterns of what he terms the "fortune-telling Lapps" (Læstadius 1959, 46-60, 110-115) using modern anthropology. He also gives an account of local Stallo traditions and tries to establish their historical background in assault by the Birkarlar (Læstadius 1959, 131-169).

Læstadius' adoption of a broad concept for mythology makes it somewhat difficult, however, to obtain a grasp of how he conceives of the status of traditional Saami beliefs at the time. He is adamant in his refusal to accept that Saami Christian belief and practice were still coloured by old sacrifice cults and consequently "in many places a heathen Christianity". It particularly irritated Læstadius that such thoughts were spread abroad by benevolent representatives of the Swedish Missionary Society (Læstadius 1959, $73 \mathrm{ff}$.).

Læstadius himself seems to have been of the opinion that "the Lapps' earlier mythology has presumably been lost" and the worship of preChristian deities had therefore ceased (Læstadius 1959, 23; cf. Læstadius $1978,28)$. At the same time there occur what can be regarded as "false belief and superstition", which can nonetheless be understood when seen in the light of anthropological or psychological theories (Læstadius 1959, 
23 and $107 \mathrm{ff}$.). To this should be added what can be characterised as "the Lapps' saga traditions" (Læstadius 1959, 127-169). Læstadius seems not to be entirely unwilling to prefer the second and third category of mythological beliefs within the framework of Saami folk Christianity.

Læstadius completed his Ancient Tales of God and Men in December 1843. The work represents the continuity between the first and the second phase of Læstadius' ministry. Fragmenter i Lappska Mythologien was not, in fact, completed until 1845 (cf. Læstadius 1959, 73-77). This means that the work continues from the first to the third phase. It is now time to turn to these two later periods of Læstadius' development.

\section{Læstadius' personal and pastoral transformation}

When it comes to Læstadius' attitude towards the old religion of the Saamis, the dramatic and personally enriching development that he experienced in conjunction with his pastoral examination in Härnösand and his inspection of the Saami parishes can possibly be regarded as a transition phase. It is inevitable, however, that a person's attitude towards another religion should be influenced by changes and transformations in his attitude towards and his interpretation of key aspects of his own religion. This was primarily what took place in Læstadius during the time between July 1843 and May 1844 and it was to have direct consequences for his ministry during the third period. The period 1843-44 is an important one for the development of Læstadianism as the "religion of the Saamis" "for it was then that Læstadius met his Maria.

If we go beyond Læstadius' own autobiography and examine available primary materials-principally his dissertations for his pastoral examination in October 1843 and his inspection report-we find that there was much that challenged and enriched Læstadius and affected his personal and pastoral transformation during these intensive months. It was his personal experience of the Brandell revival which he had read about earlier and with which he now came face to face in the persons of the deputy dean in Härnösand, Pehr Eric Bylund, and the Föllinge Saami, Milla Clemensdotter. They gave him a deeper and more differentiated view of the church's work in the areas inhabited by the Saamis and it was in particular the experiences of the Swedish Missionary Society's mission schools for Saami youngsters in the parish of Lycksele and the meeting with the catechists Carl Ludvig Tillström and Fredrik Nordberg that gave rise to Læstadius' decision to continue his parish work in Karesuando while conditions at Arvidsjaur, Arjeplog and Vittangi left much to be desired. It was also the 
confrontations that took place at Sorsele, where Læstadius stand in favour of the old readers against his former colleague Anders Fjellner. In addition, there was also his own adaptation of new experiences. Gunnar Wikmark has given a complete report on this material in the work quoted earlier, in which he also summarises his detective work that preceded the identification of Læstadius' Maria (Wikmark 1980, 132-277, concerning Maria 182-241).

If we regard Læstadius' Dårhushjonet. En blick $i$ Nådens ordning (The Asylum Servant. A Look into the Order of Grace) as the complete theological expression of his attitude as a parish priest critical of the church and as a revivalist after 1844, then we can look upon the theses laid down in his pastoral examination in October 1843 as an indication of where he stood ecclesiastically and theologically before the eventful inspection tour of Lapland.

In these theses Læstadius defends his theological position as he adapts it and develops it further in Darrhushjonet. He maintains that the subject of faith is to be sought in the heart (Læstadius 1949, tes IX) and he assumes that the recent convert cannot be unaware of his change of heart (Læstadius 1949, tes VI) but rather is able to remember the different stages of his conversion (Læstadius 1949, tes VII). Even as early as October 1843 Læstadius expressed the same criticism of supposedly rationalist features in the new baptism ceremony in the 1811 Prayer book of the Swedish Church as he later developed further in Dårhushjonet (Læstadius 1949, $\S \S 1565-1578$ ) and which caused him to sympathise with the old readers of Sorsele (Læstadius 1949, tes I; HDA F III bf 11, 1844 a, § 1), Læstadius also explains the Christian theological basis of his struggle against the sale of strong drink and the abuse of alcohol in Lapland and criticises any commitment to teetotalism which "preaches of teetotalism rather than of Christianity" (Læstadius 1949, tes XI).

As far as we are concerned there are two features of Læstadius' theses which are of particular interest. The first is that in his last thesis, written in the north Saami dialect, he maintains that "a Lapp is a better kind of human being than one who resides in a fixed place or who is not a Lapp" (Læstadius 1949, tes XII).

This thesis is notable for two reasons. From the purely formal point of view it is an innovation. Up to then the theses Lastadius had composed for the pastoral examination had been written mainly in Latin. (Thesis XI on the Christian basis for teetotalism is, however, in Finnish.) More important, however, is the connection between the thesis and our question of Læstadius' attitude towards Saami religion. The thesis conforms with Læstadius' understanding attitude, as expressed in Fragmenter i Lappska Mythologien, 
and explains his commitment to north Saami as a written and church language. It is given further consideration in his view of "uneducated people's opinion of the soul' in Darhushjonet.

The second feature of the theses that deserves our attention is that not one of them deals specifically with atonement. What Læstadius regarded as rationalist efforts to water down traditional theological teaching on atonement was, however, extremely topical even in 1843. Martensen's Moralfilosofiens system (Systems of Moral Philosophy) had already been published in Swedish translation in 1841. In 1843 Nils Ignell's Granskning af den evangelisk-luthersk Trosbekännelsens förnämsta hufuudstycken (An Examination of the Main Theses of the Evangelical-Lutheran Faith) had appeared. The same year saw a Swedish translation of the Roman Catholic theologist J. A. Möhler's comparison of the principal features of Catholic and Protestant theology. In view of the very important role played by atonement theology in Darhushjonet it is actually remarkable that Læstadius does not address the problem in the theses for his pastoral examination.

This should of course, not be seen as an indication that Læstadius was unfamiliar with classic atonement thinking prior to his meeting with the Saami girl Maria. His Boxing Day sermon in 1842 and the fine chapter 79 about God's promises of a Redeemer in Ancient Tales of God and Men suffice to show that this cannot have been the case. Rather, the absence of any explicit comment on atonement in the theses should be interpreted in quite another way. At a time when the official attitude of the Swedish Church towards nascent revivalism was becoming more severe-George Scott had been deported in 1842-Læstadius considered it relevant to offer a justification for a more modified attitude in the form of a theological comment. He also took the side of the old readers in one acute dispute-the form of the baptism ceremony. Seen in the light of Darrhushjonet, it is clear that this attitude-and Lxstadius' earlier pronouncements-was not enough for a comprehensive development of the atonement problem.

From 1844 on it became increasingly obvious to Læstadius that atonement constituted a double problem. Partly it was a question of understanding the opposition between God's love and his righteousness which precedes the act of atonement. Partly it was also experienced how atonement was to be the question within the individual believer's reach and how this process could be understood psychologically and theologically. Both questions were naturally closely related and constituted what might be termed the double problem of atonement.

Læstadius' earlier teaching on the subject of atonement had, in a very committed way, locally adapted the predominant interpretation of the first 
and superordinate theological component of the problem. His experiential comment in the theses forestalls, however, what was to become his pastoral contribution in Darhushionet and what gave concrete expression and directness to his teaching after his homecoming in May 1844. The meeting with Milla Clemensdotter at Åsele in early January that year gave further inspiration to this personal and pastoral transformation.

\section{Læstadius as parish priest and revivalist critical of the established church}

As I have already pointed out it was not least Læstadius' experiences of pastoral work among the Saamis in Lycksele parish with its three separate mission schools and enthusiastic catechists that inspired and stimulated him to form his new strategy for his work among the Saamis of the Karesuando parish. Summing up the situation in Karesuando in May 1844, Læstadius was forced to admit a more acute problem than the lack of fixed educational localities for the Saami youngsters. In his comparison with conditions in Lappland generally he found the situation in Karesuando as far as the knowledge of Christianity was concerned "much better than at Arjeplog, Gellivare and Jukasjärvi"' (HDA F III bf 11, 1844b). However, it was only "dead knowledge" unable to withstand the temptation of strong drink. He therefore appealed to the authorities to take measures against the sale of alcohol (HDA F III bf 11,1844 b). His efforts as parish priest and revivalist critical of the established church would continue to be directed especially towards the abuse of strong drink in Lappland.

With Læstadius' move to Pajala, where the great majority of the congregation consisted of Finnish-speaking settlers, his direct contacts with the world of the Saamis changed. The first period of Læstadius' ministry was marked, as we have seen, by intensive and close links with Saami villages and communities. After the success of the revival in 1845 and his move to Pajala in 1849, however, it was his interest in the Læstadian movement which dominated his life. Læstadius was forced to act as both religious leader of the people and arbitrator between the revivalists and the established authorities of the church and of society (see e.g. $\$ \S 21-23$ in A. Högström's official report of Bishop I. Beckman's inspection tour of Pajala, July $30-31,1853$ ).

Despite this change in the actual framework of Læstadius' ministry, his personal and pastoral transformation seems to have meant a somewhat different attitude to Saami religion. In content Læstadius' work was characterised partly by his endeavours to create a more direct preaching style that 
would lead to "the more vigorous practice of the Christian religion" (cf. Læstadius' report of his inspection tour, January-May 1844) and partly by his further consideration of the theoretical and practical implications of the question of atonement.

As regards the matter of Læstadius' "new teaching" he himself described his intentions as a desire to paint in "more vivid colours". His daring, at times even drastic, imagery was very characteristic of him.

In his struggle against the Saamis' abuse of alcohol Læstadius' homiletic-and perhaps rhetorical-approach led to a new angle in his attitude to the mythological heritage of the Saamis. In his Boxing Day sermon Læstadius placed the Saamis abuse of alcohol on a par with "idolatry", something which belonged to the past. In another work, a discussion between a Christian and an ordinary person (Nobbe Hålaitettem Ristagasa ja Satte Almatja Kaskan; Læstadius 1847), which is a direct attack on the trade in strong drink and the abuse of alcohol among the Lapps, Læstadius went one step further. In this work he did not regard the Saami religion as something exclusively out of date. Instead, he put his message in a more concrete form by making use of Saami ideas. Læstadius talked forcefully about the threat of "the evil alcohol" which exploits the Saamis and holds them captive (Læstadius 1978, 20). He was also able to refer to Saami conditions. He describes the drunken Saami as "one who sings and wails like a dog in heat that has lost its bitch to other mongrels" (Læstadius 1978, 15). He compares someone who persists in his abuse of alcohol with "a wild reindeer pursued by the wolf" (Læstadius 1978, 24). What Læstadius particularly lashes out against is indulgence in strong drink in connection with church-going and receiving holy communion (Læstadius 1978, passim).

Against the background of this conscious use of very concrete language in his communications with the Saamis after 1844, which certainly contributed to a large extent to the fact that Læstadianism became "the religion of the Saamis" ", it becomes tempting to ask whether Læstadius tried to be equally concrete when talking about "heavenly things", not least about atonement. An answer to this question may be found perhaps in Dårhushjo$n e t$, even though this work is a qualified theological dissertation at a high level of abstraction and not so much a medium for direct communication with the Saamis.

Dårhushjonet is probably one of the most remarkable and interesting products of 19th-century Swedish theology. Not until very recently has it been available to a wider public. Had it been within the ordinary people's reach during the atonement disputes of the latter part of the 19th century, disputes which split the new evangelical movement, it would probably have 
resulted in quite a different outcome for this exchange of opinion-and indeed for Swedish ecclesiastical history in general.

As has already been indicated, Læstadius' treatment of the double problem of atonement constitutes the main theme of this work. He bases his solution to the problem, however, on very ambitious theoretical and psychological reasoning in which he makes independent use of contemporary anthropological insights into "the passions", i.e. man's baser instincts (cf. Bäcksbacka 1937; Åberg 1961).

It is characteristic of Læstadius' approach to the double problem of atonement that-briefly-he holds fast to the substance of the classic teaching on atonement of Anselm but does not lay it down in legal terms but within the framework of a personal relationship between "the heavenly parent" and the prodigal but reconciled son (Læstadius 1949, $\S \S 1252-1270$ ). When Læstadius illustrates the inner side both in the conflict between the demands of righteousness and the love shown by the deity and in the struggle between fear and the devil's temptations, he consciously chooses the image of the loving mother who bewails and seeks her lost child. He describes the conflict within the mother between right and love by means of concrete images and he pities the mother whose sense of righteousness becomes an infernal passion that kills maternal love. Such a mother is a reflection of the Law without the Gospel (Læstadius 1949, $\S 1286-1291)$. At the same time Læstadius describes most dramatically how the lost but reconciled person must first accuse himself of "matricide" and hate of the self-sacrificing mother (Læstadius 1949, § 1299) as a struggle against the devil's self-righteousness, which does not allow of a given atonement (Læstadius 1949, §§1330-1336). Læstadius also makes clear how the encounter with the reality of atonement can provide "a foretaste of heavenly bliss" (Læstadius 1949, §1339) which can be experienced once more during proper partaking of Holy Communion (Læstadius 1949, $\S 1282)$.

Læstadius is aware that this adaptation of the anthropological framework for the dedication to atonement carries traditional atonement theology a step further, especially atonement seen as "a psychic act" (Læstadius $1949, \S 1282$ ). His mention of "the heavenly parent" and the use of mother symbolism are also new in this context.

More than anyone else it is Hjalmar Sundén who has directed his attention to these facts. He has placed them on a footing with Læstadius' own account of his meeting with Maria and tried to explain the problems with the aid of role-psychological analysis. The significance of the Saami woman Maria for Lastadius according to this approach is that she re-actualises the image of his mother and liberates it so that it can serve as a mirror of the 
Saviour, the Redeemer (cf. Sundén 1959, 231). If we so wish, we might say that Læstadius's treatment of the atonement theme in Dårhushjonet reflects what we might term his Saami mother tongue.

With reference to what we have already discovered about the way in which Læstadius, subsequent to 1844, consciously made use of elements of Saami mythology when he wished to give an important message to his Saami listeners (and readers), it is tempting to take a step in a different direction from Sundén in our attempt to understand Læstadius' conscious imagery in Dårhushjonet. Does this reflect anything more or other than Læstadius' own relationship to his mother?

As Læstadius makes clear in Fragmenter in connection with E. J. Jessen, above all, the existence of the mother gooddess (Madder-akka) and other female deities was something extremely concrete in Saami pre-Christian religion (Læstadius 1959, 35 ff.). In Læstadius' time conceptions and the worship of these deities had ceased (Læstadius 1959, 23). Despite this, Læstadius may have found it of value, in a living Saami interpretation of Christianity, to give a more rounded picture of the deity that was expressed in Christian usage by the old Saami god of thunder and sky, Jubmela (Læstadius 1959, $42 \mathrm{ff}$. about Jubma and Jubmel) by keeping alive the mother aspect of "the heavenly parent". Therefore he may have consciously chosen to use mother symbolism when talking of the secret of atonement-not least to the Saamis.

I leave this question open at this stage. The problem must be studied more closely by means of a structural analysis of Læstadius' theology and language, especially in his writings in the northern Saami dialect. It is my opinion, however, that in any discussion of how Læstadianism became "the religion of the Saamis" it is impossible to ignore the fact that Læstadius was not alien to a locally adapted Saami interpretation of Christianity. In modern terms we might say that Læstadius did not reject the problem of contextualisation. In this, however, he did not go so far as his earlier colleague Anders Fjellner. Fjellner represented quite different ideals from those of Læstadianism in Saami religious and ecclesiastical history of the 19 th century.

\section{Bibliography}

UNPUBLISHED SOURCES AND LITERATURE

\section{Härnösand}

HDA Härnösands landsarkiv

Härnösands domkapitels arkiv

F III bf 11. Læstadius, L. L. 1836. Ämbetsberättelse 4.2.

F III bf 11. Læstadius, L. L. 1844 a. Visitationsberättelse, Sorsele 27. 1. 
F III bf 11. Læstadius, L. L. 1844b. Visitationsberättelse, Karesuando 17. 5.

F IX a 4. Læstadius, L. L. 1842. Brev till konsistoriet i Härnösand 27. 5.

\section{PUBLISHED SOURCES AND LITERATURE}

Bäcksbacka, E. 1937. Lars Levi Læstadius' religionsfilosofiska arbete "Dårhushjonet", dess tillblivelse och syfte. Finska Kyrkohistoriska Samfundets årsskrift. Helsingfors.

Högström, P. 1747. Beskrifning öfwer de til Sweriges Krona lydande Lapmarker. Stockholm.

Læstadius, L. L. 1839. Hålaitattem Ristagasa ja Satte Almatja kaskan. Vuostas håålla. Mässo måkkest. Hernöșandesne.

- 1842. Prediko Nobbe Jåluå Peiwen naln, maw lå tjalam. Hernösandesne.

- 1844. Tåluts Suptsasah, Jubmela pirra ja Almatji pirra. Hernösand.

- 1847. Nobbe Hålaitettem Ristagasa ja Satte Almatja kaskan. Stockholm.

- 1949. Dårhushjonet 1-2. [Ed. by] E. Bäcksbacka. Helsingfors.

- 1959. Fragmenter i Lappska Mythologien. [Ed. by] H. Grundström. Svenska Landsmål B, 61. Uppsala.

- 1978. Saamenkieliset saarnat ja kirjoitukset. Samiska predikningar och skrifter. [Transl. to Finnish by] L. Mustakallio; [transl. to Swedish by] G. Gripenstad. Helsinki.

Sundén, H. 1959. Religionen och rollerna. Stockholm.

Wikmark, G. 1980. Lars Levi Læstadius' väg till nya födelsen. (Samlingar och studier till Svenska kyrkans historia 43.) Stockholm.

Ăberg, B. 1961. Första delen av Læstadius' "Dårhushjonet" återfunnen. Kyrkohistorisk årsskrift. Uppsala.

\section{Appendix}

Læstadius' arrangement of his visitations to the Lapp population of Karesuando parish (29 March 1836).

For the preservation of the Christian knowledge bestowed by these zealous predecessors (David Engelmark, Erik Grape and Zacharias Grape), and to contribute in some degree to its increase particularly among younger persons the undersigned, together with the missionary Mr And Fjellner, has visited the Lapps in their proper habitation, wherein occasion was provided not merely to observe each person's morals and progress in Christian knowledge but also to provide teaching in accordance with the people's powers of understanding.

Although it may seem immaterial which method is normally used for general examinations of the Catechism, it may nevertheless be useful to set down which method was employed by the undersigned during his tent hearings among the Lapp peasantry.

On arrival at a tent settlement, which may consist of 10 to 15 people, no reading could be performed when arriving in the evening because of the various household tasks in which the Lapps are engaged at that time of the 
day. During the period preceding the evening meal it was not considered suitable to engage in anything but general discussion about the structure of the world, the movement of the heavenly bodies and the nature of the earth etc. since circumstances permitted this.

After the evening meal the whole tent settlement is summoned to prayer, after which a short examination is conducted among the older members concerning the highest principles of Christianity. These examinations consist mainly of questions in order to establish the concept itself.

From these questions to test the understanding it was customary to move imperceptibly to oral accounts of biblical history from the Old and New Testament, which being applied to public and private life were continued far into the night, or as long as they seemed to hold the attention of those present.

In the morning in broad daylight the settlement is again called to prayer, after which reading tests are conducted with both older and younger people. Those texts from the gospels chosen for reading aloud are selected for the opportunities they provide for further explanation of Christian requirements.

At the end of the examination the journey was continued to another village, for which purpose tax paying householders in the settlement provide reindeer and guide.

These tent interrogations apparently have the benefit of allowing no-one to evade them on the pretext of lawful hindrance, with the exception of those who are absent at that time, who it is usually possible to meet however at another settlement or during another year; so that the negligent ones may be personally warned and when no improvement occurs, they are finally obliged to come to confirmation school to recive instruction. Experience has shown that when certain groups were called to church or to the neighbouring village, the most ignorant and those most in need of instruction remained by their tents with the excuse that they were taking care of the home and the reindeer herd. Without visiting house and property it was not possible to oblige everyone to attend an examination not held at their own tent. 